\title{
PEMENUHAN PENILAIAN KINERJA GURU (PKG) BAGI GURU SDN. 101801 DAN SDN. 108075 KECAMATAN DELI TUA KABUPATEN DELI SERDANG
}

\author{
Halimatussakdiah, Khairul Anwar \\ Dosen Jurusan PPSD Prodi PGSD FIP UNIMED \\ Jln. Willem Iskandar Psr. V. Kotak Pos No. 1589-Medan 20221 Telp.(061)6623943 \\ Surel: halimatussakdiahnst11@gmail.com
}

\begin{abstract}
Abstrak
Pemenuhan PKG dengan menerapkan metode tutor sebaya merupakan strategi yang diharapkan dapat meningkatkan kompetensinya baik pada dimensi pedagogik, kepribadian, sosial dan professional. Metode penelitian ini deskriptif kualitatif. Lokasi Penelitian ini dilakukan di SDN. 101801 dan SDN 108075 Kecamatan Deli Tua Kabupaten Deli Serdang. Kegiatan ini dilaksanakan dari Juni s.d November 2015 di SDN. 101801 dan SDN. 108075 Kecamatan Deli Tua Kabupaten Deli Serdang. Berdasarkan penerapan metode tutor sebaya dalam Pemenuhan Penilaian Kinerja Guru (PKG) dari 36 orang guru terdapat 7 orang $(19,44 \%)$ pada kategori baik, 12 orang $(33,33 \%)$ pada kategori cukup, 9 orang (25\%) pada kategori sedang, 8 orang $(22,22 \%)$ pada kategori kurang. Selanjutnya rata-rata kompetensi guru yaitu 65,23 berada pada kategori cukup.
\end{abstract}

Kata Kunci: Pemenuhan, PKG, Metode Tutor Sebaya

\section{PENDAHULUAN}

Guru merupakan sumber daya utama dalam mencerdaskan kehidupan bangsa dan berada pada posisi terdepan bagi pencapaian tujuan pendidikan. Guru harus dapat memfasilitasi proses pembelajaran dan memperhatikan perkembangan peserta didik dalam berbagai dimensi yang mengarah kepada pengembanan inteligensi, keterampilan belajar, sikap, dan kemandirian peserta didik dengan tetap berpegang pada fungsi dan tujuan pendidikan nasional. Sehubungan dengan itu, guru dalam kinerjanya dituntut untuk selalu memperbaharui dan meningkatkan kompetensinya baik pada dimensi pedagogik, kepribadian, sosial dan professional.
Kompetensi pedagogik, guru menguasai karakteristik peserta didik, menguasai teori belajar dan prinsip-prinsip pembelajaran yang mendidik, pengembangan kurikulum, kegiatan pembelajaran yang mendidik, pengembangan potensi peserta didik, komunikasi dengan peserta didik dan penilaian dan evaluasi. Kompetensi kepribadian, guru bertindak sesuai dengan norma agama, hukum, sosial dan kebudayaan nasional indonesia, menunjukkan pribadi yang dewasa dan teladan, etos kerja, tanggung jawab yang tinggi, dan rasa bangga menjadi guru. Kompetensi sosial, guru bersikap inklusif, bertindak objektif, tidak diskriminatif dan mampu 
berkomunikasi sosial dengan siswa, sesama rekan guru, kepala sekolah, dan masyarakat. Kompetensi professional, guru menguasaai materi, struktur, konsep dan pola pikir keilmuan yang mendukung mata pelajaran yang diampu, mengembangkan keprofesionalan melalui tindakan reflektif.

Dengan demikian, empat kompetensi tersebut dianggap sebagai variabel kritis dalam meningkatkan kinerja guru sebagai pendidik professional. Apabila pemenuhan empat kompetensi tersebut dapat dilaksanakan dengan baik dan objektif, maka guru dapat menemukan kinerjanya secara tepat di dalam kelas dan membantu mereka untuk meningkatkan pengetahuan dan keterampilannya. Sehingga akan memberikan kontribusi secara langsung pada peningkatan kualitas pembelajaran yang dilakukan di kelas, sekaligus membantu pengembangan karir guru sebagai tenaga profesional. Hal tersebut senada dengan Peraturan Menteri Negara Pendayagunaan Aparatur Negara dan Reformasi Birokrasi Nomor 16 Tahun 2009 tentang Jabatan Fungsional Guru dan Angka Kreditnya, agar tugas dan fungsi yang melekat pada jabatan fungsional guru maka dilaksanakan sesuai dengan aturan yang berlaku. Pemenuhan terhadap pelaksanaan tugas dan kewajiban guru dalam melaksanakan pembelajaran, pembimbingan dan tugas-tugas tambahan yang relevan dengan fungsi sekolah menjadi kewajiban yang harus dipatuhi. Oleh karena itu untuk meyakinkan bahwa setiap guru adalah seorang profesional di bidangnya dan sebagai penghargaan atas prestasi kerjanya, maka pemenuhan butir-butir penilaian kinerja guru yang disyaratkan menjadi penting untuk dilaksanakan oleh guru di sekolah.

Analisis awal pada 2015 (Januari s.d Maret) terhadap 36 orang guru SD di 101801 dan SDN. 108075 Kecamatan Deli Tua Kabupaten Deli Serdang ditemukan permasalahan bahwa guru belum memenuhi butir-butir kinerja guru yang disyaratkan sesuai dengan Peraturan MENPAN dan RB No.16 Tahun 2009 yaitu: (1) Kompetensi pedagogik, guru kurang menguasai karakteristik peserta didik, tidak menguasai teori belajar dan prinsipprinsip pembelajaran yang mendidik, kurang mengembangkan kurikulum, kurang mengembangkan potensi peserta didik, dan kurangnya mengembangkan instrumen penilaian. (2) Kompetensi kepribadian, guru kurang bertanggung jawab, kurang disiplin, suka marah, datang terlambat dan sering meninggalkan kelas untuk bergosip sesama guru di ruang guru. (3) Kompetensi sosial, guru kurang bersikap inklusif, belum bertindak objektif, diskriminatif dan kurang bersahabat. (4) Kompetensi professional, guru belum menguasaai materi, struktur, konsep dan pola pikir keilmuan yang mendukung mata pelajaran yang diampu, kurang mengembangkan keprofesionalan 


$\begin{array}{lrll}\text { melalui tindakan } & \text { reflektif. } & \text { dideskripsi berdasarkan } & \text { grafik } \\ \text { Permasalahan tersebut } & \text { dapat } & \text { berikut: }\end{array}$

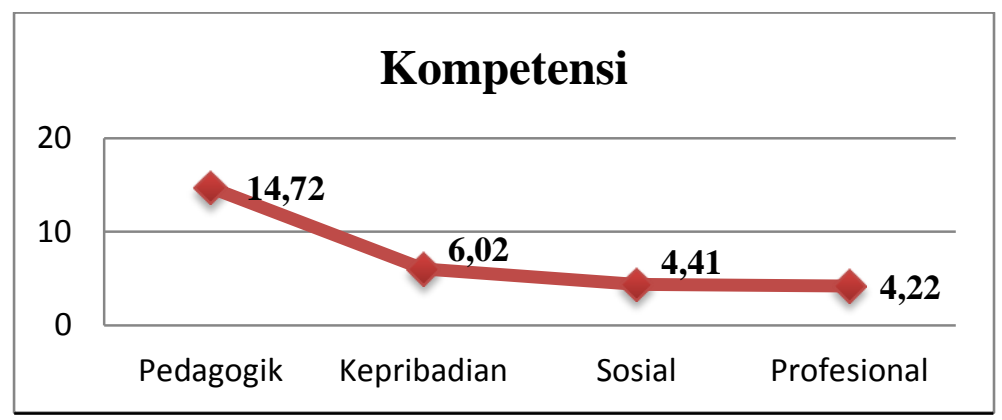

Gambar 1. Rata-rata pemenuhan empat kompetensi guru SDN. 101801dan SDN. 108075

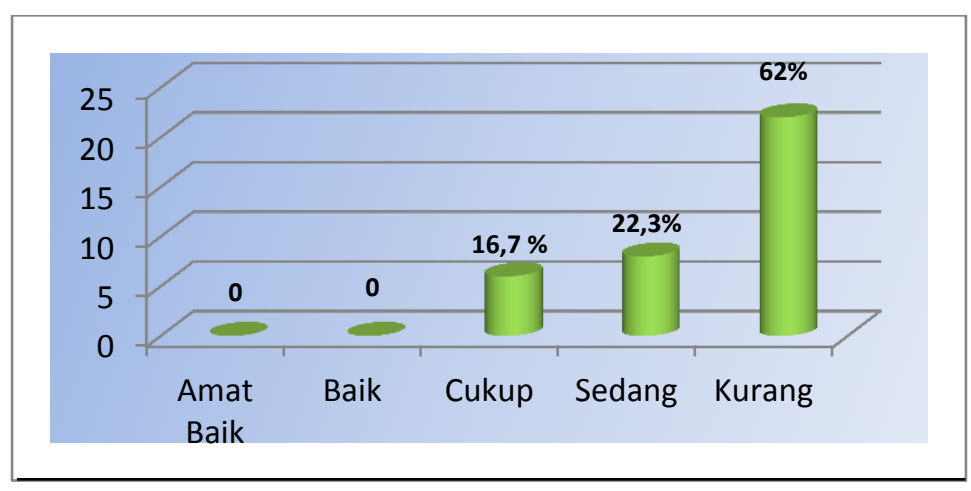

Gambar 2. Kategori Pemenuhan PKG SDN. 101801 dan SDN. 108075

Permasalahan yang dihadapi guru seperti digambarkan pada grafik di atas disebabkan karena kekurangpahaman guru sebagai seorang pendidik profesional. Guru tidak memenuhi keprofesiannya sebagai guru. Seyogianya guru menguasai empat kompetensi (pedagogik, kepribadian, sosial dan profesional), namun pada kenyataannya guru belum memenuhi empat kompetensi tersebut. Hal tersebut dapat dibuktikan dari rendahnya pencapaian empat kompetensi tersebut yaitu pedagogik $(14,72 \%)$, kepribadian $(6,02)$, sosial $(4,41 \%)$ dan profesional $(4,42 \%)$.
Akibat rendahnya pencapaian tersebut, guru kesulitan dalam menyusun PKG untuk diusulkan kenaikan fungsionalnya. Apalagi setelah Pemerintah menetapkan aturan baru kenaikan pangkat, hal ini dapat dibuktikan dari 36 orang guru terdapat 22 orang (62\%) pada kategori kurang, 8 orang $(22,3 \%)$ pada kategori sedang, 6 orang (16,7\%) pada kategori cukup, dan tidak ada yang memenuhi kategori baik dan amat baik. Guru dikatakan memenuhi syarat dalam PKG apabila guru berada pada kategori baik (rentang nilai 76-90) dan amat baik (rentang nilai 91-100), namun guru 
tidak memenuhi kategori tersebut karena berada pada kategori cukup (rentang nilai 61-75), kategori sedang (51-60) dan kategori kurang (rentang nilai $\leq 50$ ).

Ketidakmampuan guru juga terlihat pada nilai rata-rata kemampuan guru dalam memenuhi PKG termasuk kategori sedang $(52,55)$.

Berdasarkan kenyataan diatas, maka perlu dicari alternatif sehingga Pemenuhan Penilaian Kinerja Guru (PKG) bagi guru dapat terlaksana dengan efektif. Salah satu pendekatan y ang diduga mampu mewujudkan situasi terpenuhinya PKG dengan proses y ang kondusif; aktif, kreatif, efektif, dan menyenangkan adalah dengan metode tutor sebaya.

Melalui tutor sebaya ini guru sebagai peserta bukan hanya dijadikan sebagai objek pembelajaran tetapi menjadi subjek pembelajaran, yaitu guru dimotivasi untuk menjadi tutor atau sumber belajar dan tempat bertanya bagi temannya. Dengan cara demikian guru yang menjadi tutor melakukan repetition (pengulangan) dan menjelaskan kembali materi sehingga menjadi lebih $\mathrm{p}$ aham dalam setiap materi PKG y ang $d$ isampaikan peneliti dari tim dosen Unimed.

Berdasarkan latarbelakang di atas, menunjukkan betapa urgennya permasalahan yang dihadapi guru dan pentingnya untuk segera ditangani secara sistematis dan terarah. Dengan demikian penelitian mendalam perlu dilakukan sebagai evaluasi dan refleksi bagi guru-guru SDN. 101801 dan SDN. 108075 Kecamatan Deli Tua Kabupaten Deli Serdang. Penelitian yang dilakukan oleh tim dosen dari Unimed ini berusaha memberi solusi kepada guru untuk bisa mendapatkan masukan dalam menyusun dan memenuhi syarat Penilaian Kinerja Guru (PKG) melalui metode tutor sebaya. Diharapkan setelah kegiatan ini berlangsung, maka dapat tersampaikan kebijakan pemerintah tentang penilaian kinerja guru dan terbentuknya tim penilai $\mathrm{PKG}$ di sekolah.

Setelah memahami fakta di lapangan, terhadap kendala-kendala yang dihadapi SDN. 101801 dan SDN. 108075 Kecamatan Deli Tua Kabupaten Deli Serdang, fokus kajian penelitian ini yaitu: apakah penerapan metode tutor dapat memenuhi Penilaian Kinerja Guru (PKG) bagi guru-guru SDN. 101801 dan SDN. 108075 Kecamatan Deli Tua Kabupaten Deli Serdang.

Tujuan kegiatan ini adalah meningkatkan kemampuan guru dalam memenuhi butir-butir Penilaian Kinerja Guru (PKG) melalui metode tutor sebaya. Manfaat teoritis penelitian ini dapat menambah pemahaman terhadap pendekatan teori dan strategi pembelajaran melalui pembelajaran tutor sebaya. Selanjutnya manfaat praktis kegiatan ini adalah sebagai berikut : (1) guru dapat memperbaiki 
pembelajaran (misalnya menerapkan pendekatan, model, metode, strategi, dan media) di kelas dan melakukan tindakan baru yang ditemukan serta diyakini guru bisa secara efektif meningkatkan proses dan hasil belajar siswa di kelas, (2) dapat dijadikan sebagai motivator agar sekolah terus meningkatkan mutu pendidikan secara bertahap dan terencana, (3) dapat dijadikan umpan balik dalam usaha pemberdayaan dan pengembangan kinerja warga sekolah dalam rangka menerapkan visi, misi, tujuan, sasaran, strategi dan program sekolah, (4) membantu mengidentifikasi sekolah dalam rangka pemberian bantuan pemerintah, investasi dana swasta dan donatur atau bentuk bantuan lainnya, (5) menghasilkan strategi pembelajaran efektif dan inovatif yang dapat dijadikan sebagai sumber belajar pada Prodi PGSD FIP Unimed.

\section{METODOLOGI PENELITIAN}

Dengan permasalahanpermasalahan sebagaimana digambarkan sebelumnya dan untuk mencapai tujuan kegiatan penelitian ini, maka metode penelitian ini adalah penelitian deskriptif kualitatif.

Lokasi Penelitian ini dilakukan di SDN. 101801 dan SDN 108075 Kecamatan Deli Tua Kabupaten Deli Serdang. Lokasi ini dianggap mewakili sekolah yang berada di daerah pinggiran tetapi mewakili akses yang baik dalam transportasi dan komunikasi ke daerah perkotaan. Waktu pelaksanaan penelitian dilaksanakan selama 6 bulan, terhitung mulai Juni sampai dengan November 2015.

\section{Sumber Data}

Sumber data dalam penelitian ini adalah guru SDN. 101801 dan SDN 108075 Kecamatan Deli Tua Kabupaten Deli Serdang yang berjumlah 36 orang.

\section{Teknik Pengumpulan Data}

Data dikumpulkan melalui observasi, dokumentasi, dan wawancara mendalam. Observasi dilakukan untuk mengamati pelaksanaan dan perkembangan pembelajaran guru di kelas. Pengamatan dilakukan sebelum, selama, dan sesudah penelitian berlangsung. Wawancara dilakukan terahadap Kepala sekolah, guru, siswa dan masyarakat guna menggali informasi berkaitan dengan aspekaspek pembelajaran di sekolah.

\section{Teknik Analisis Data}

Data yang terkumpul dianalisis secara deskriptif kualitatif. Menghitung persentase data penelitian yang diperoleh menggunakan formula sebagai berikut:

Skor yang diperoleh $\mathrm{X} 100 \%=\ldots \%$ Skor masimal 
Selanjutnya menentukan nilai ratarata menggunakan rumus sebagai berikut:

$$
M=\frac{\sum \mathrm{x}}{\mathrm{N}}
$$

Ket :

$\mathrm{M}=$ Rata-rata skor

$\mathrm{N}=$ Jumlah Subjek $\sum \mathrm{x}=$ Jumlah skor $\mathrm{x}$

Tingkat keberhasilan ditentukan dengan melihat dari kriteria keberhasilan yang telah ditetapkan sebagaimana diatur dalam Permennegpan dan RB No. 16 Tahun 2009.

Tabel 1. Kriteria Keberhasilan

\begin{tabular}{|c|c|c|}
\hline $\begin{array}{c}\text { Nilai Hasil } \\
\text { Penilaian Kinerja } \\
\text { Guru (PKG) }\end{array}$ & Kategori & $\begin{array}{c}\text { Persentase Angka } \\
\text { Kredit }\end{array}$ \\
\hline $91-100$ & Amat Baik & $125 \%$ \\
\hline $76-90$ & Baik & $100 \%$ \\
\hline $61-75$ & Cukup & $75 \%$ \\
\hline $51-60$ & Sedang & $50 \%$ \\
\hline$\leq 50$ & Kurang & $25 \%$ \\
\hline
\end{tabular}

HASIL PENELITIAN DAN PEMBAHASAN

Hasil PKG guru dapat bermanfaat untuk menentukan kebijakan yang terkait dengan peningkatan kompetensi dan profesionalisme guru sebagai ujung tombak pelaksanaan proses pendidikan dalam menciptakan insan yang cerdas dan komprehensif. PKG merupakan acuan bagi sekolah untuk menetapkan pengembangan karir dan promosi guru. Selanjutnya, bagi guru PKG merupakan pedoman untuk mengetahui unsur-unsur kinerja yang dinilai dan sebagai sarana untuk mengkaji kekuatan dan kelemahan individu dalam rangka memperbaiki kualitas kinerjanya. Penelitian ini dilakukan bertujuan untuk mengetahui sejauhmana pemenuhan
PKG melalui metode tutor sebaya bagi Guru SDN. 101801 dan SDN.108075 Kecamatan Deli Tua Kabupaten Deli Serdang. Berdasarkan observasi yang dilakukan di SD Kecamatan Deli Tua tahun 2015, dapat di sajikan masingmasing data sebagai berikut:

\section{A. Hasil}

Berdasarkan analisis awal pada 36 orang guru SD di 101801 dan SDN. 108075 Kecamatan Deli Tua Kabupaten Deli Serdang ditemukan permasalahan bahwa guru belum memenuhi butir-butir kinerja guru yang disyaratkan sesuai dengan Peraturan MENPAN dan RB No.16 Tahun 2009 yaitu: (1) Kompetensi pedagogik, guru kurang menguasai karakteristik peserta didik, tidak 
menguasai teori belajar dan prinsipprinsip pembelajaran yang mendidik, kurang mengembangkan kurikulum, kurang mengembangkan potensi peserta didik, dan kurangnya mengembangkan instrumen penilaian. (2) Kompetensi kepribadian, guru kurang bertanggung jawab, kurang disiplin, suka marah, datang terlambat dan sering meninggalkan kelas untuk bergosip sesama guru di ruang guru. (3) Kompetensi sosial, guru kurang bersikap inklusif, belum bertindak objektif, diskriminatif dan kurang bersahabat. (4) Kompetensi professional, guru belum menguasaai materi, struktur, konsep dan pola pikir keilmuan yang mendukung mata pelajaran yang diampu, kurang mengembangkan keprofesionalan melalui tindakan reflektif.

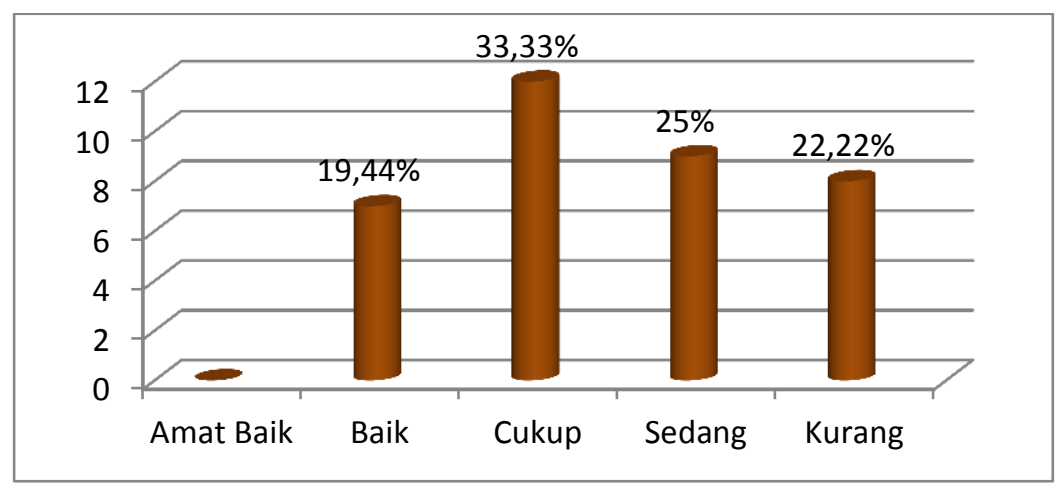

Gambar 3. Kategori Pemenuhan Penilaian Kinerja Guru (PKG) melalui penerapan metode tutor sebaya bagi guru SDN. 101801 dan SDN. 108075

Berdasarkan gambar di atas dapat dideskripsikan, penerapan metode tutor sebaya dalam Pemenuhan Penilaian Kinerja Guru (PKG) diketahui dari 36 orang guru terdapat 7 orang $(19,44 \%)$ pada kategori baik, 12 orang $(33,33 \%)$ pada kategori cukup, 9 orang $(25 \%)$ pada kategori sedang, 8 orang $(22,22 \%)$ pada kategori kurang. Selanjutnya rata-rata kompetensi guru yaitu 65,23 berada pada kategori Cukup. Penerapan metode tutor sebaya sangat baik bagi pemahaman dan kemampuan guru dalam memenuhi PKG. Melalui metode tutor sebaya, guru sebagai peserta bukan hanya dijadikan sebagai objek pembelajaran tetapi menjadi subjek pembelajaran, yaitu guru dimotivasi untuk menjadi tutor atau sumber belajar dan tempat bertanya bagi temannya. Dengan cara demikian guru yang menjadi tutor melakukan repetition (pengulangan) dan menjelaskan kembali materi sehingga menjadi lebih $\mathrm{p}$ aham dalam setiap materi PKG yang disampaikan peneliti dari tim dosen Unimed. Data 
sebelumnya rata-rata $\mathrm{PKG}$ guru 52,55 (kategori sedang), setelah penerapan metode tutor sebaya ratarata PKG guru menjadi lebih baik 65,23 (kategori cukup).

\section{B. Pembahasan}

Berdasarkan pengamatan oleh peneliti di dalam kelas, masih ada kekurangan-kekurangan guru dalam mengolah pembelajaran diantaranya : 1) guru di dalam kelas belum menggunakan strategi pembelajaran semaksimal mungkin serta penguasaan kelas sehingga membuat siswa menjadi bingung dalam menyerap pembelajaran, 2) guru juga belum mengoptimalkan keatifan kegiatan belajar siswa dalam pembelajaran karena pembelajaran hanya terfokus pada guru (teacher centered), 3) kelompok-kelompok diskusi yang dibentuk guru pun belum beraktifitas secara optimal. Mereka masih bingung apa yang harus mereka lakukan, 4) selain itu dari penilaian pembelajaran sebagian siswa belum memahami benar pembelajaran, 5) setelah simulasi dilaksanakan, tampak keberhasilan belajar belum tercapai.

Selanjutnya, penerapan metode tutor sebaya dalam Pemenuhan Penilaian Kinerja Guru (PKG) dilaksanakan dengan memberdayakan peserta sebagai tutor. Calon tutor dipilih berdasarkan beberapa kriteria, yaitu kemampuan akademik yang cukup tinggi, mampu berkomunikasi dengan baik serta memiliki kemampuan interpersonal yang baik.

Adapun langkah-langkah yang dilakukan pada penerapan metode tutor sebaya terdiri dari beberapa fase, sebagai berikut: Fasefase yang dilakukan, tentu sangat baik bagi guru SDN 108001 dan SDN 108075. Rasa saling menghargai dan mengerti dibina antar peserta yang bekerja sama. Metode ini banyak sekali manfaatnya baik dari sisi guru yang berperan sebagai tutor maupun bagi guru yang dibantu. Kerjasama yang dibina dengan baik antara tutor dan rekannya dapat dibuktikan dari hasil PKG guru yang meningkat, terlihat dari gambar

(4) ini

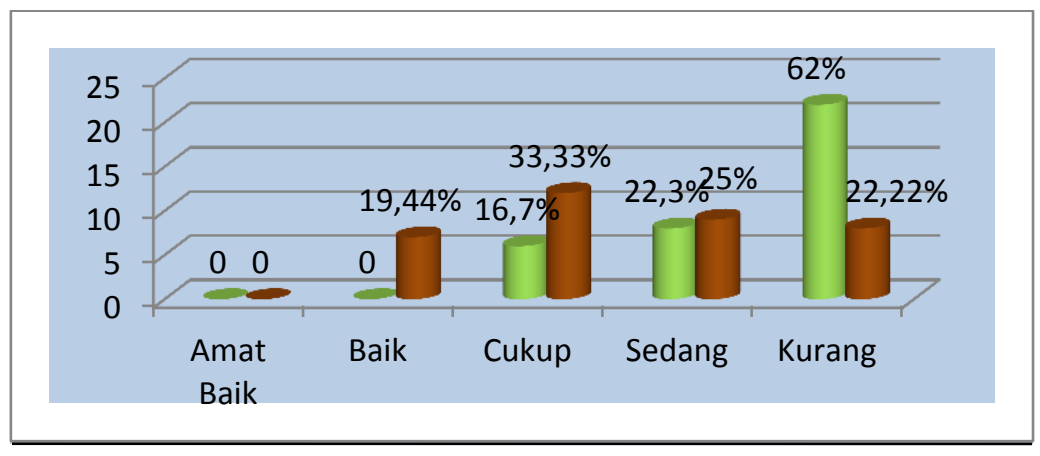

Gambar 4. Pemenuhan Penilaian Kinerja Guru (PKG) bagi guru SDN. 101801 dan SDN. 108075 
Berdasarkan grafik di atas, data awal dari 36 orang guru terdapat 22 orang $(62 \%)$ pada kategori kurang, 8 orang $(22,3 \%)$ pada kategori sedang, 6 orang $(16,7 \%)$ pada kategori cukup, dan tidak ada yang memenuhi kategori baik dan amat baik. Nilai rata-rata kemampuan guru dalam memenuhi PKG termasuk kategori sedang $(52,55)$.

Selanjutnya, ketika dilakukan penerapan metode tutor sebaya, guru yang dipilih sebagai tutor sebanyak 6 orang ditugaskan untuk menerangkan tentang materi PKG dan membantu rekannya yang lain yang mengalami kesulitan dalam memenuhi butir-butir indikator PKG. Tugas guru yang jadi peserta, mengerjakan tugas sesuai indikator PKG dan praktik. Penerapan metode tutor sebaya terlihat ada kemajuan yaitu dari 36 orang guru terdapat 7 orang $(19,44 \%)$ pada kategori baik, 12 orang $(33,33 \%)$ pada kategori cukup, 9 orang $(25 \%)$ pada kategori sedang, 8 orang $(22,22 \%)$ pada kategori kurang. Selanjutnya ratarata kompetensi guru meningkat yaitu 65,23 berada pada kategori Cukup.

\section{SIMPULAN DAN SARAN}

\section{Simpulan}

Penelitian ini dilakukan
dalam rangka mengetahui
sejauhmana pemahaman dan
kemampuan guru dalam memenuhi
butir-butir penilaian kinerja guru.
Penerapan metode tutor sebaya

menjadi solusi dalam Pemenuhan Penilaian Kinerja Guru (PKG). Berdasarkan analisis diketahui dari 36 orang guru terdapat 7 orang $(19,44 \%)$ pada kategori baik, 12 orang $(33,33 \%)$ pada kategori cukup, 9 orang $(25 \%)$ pada kategori sedang, 8 orang $(22,22 \%)$ pada kategori kurang. Selanjutnya rata-rata kompetensi guru yaitu 65,23 berada pada kategori Cukup. Sehingga dapat dijelaskan bahwa penerapan metode tutor sebaya sangat baik bagi pemahaman dan kemampuan guru dalam memenuhi PKG. Data sebelumnya rata-rata $\mathrm{PKG}$ guru 52,55 (kategori sedang), setelah penerapan metode tutor sebaya ratarata PKG guru menjadi lebih baik 65,23 (kategori cukup). Dengan demikian, penerapan metode tutor sebaya dalam pemenuhan PKG, guru dapat mengevaluasi dan merefleksi diri dengan cara memperbaiki pembelajaran (misalnya menerapkan pendekatan, model, metode, strategi, dan media) di kelas dan melakukan tindakan baru yang ditemukan serta diyakini guru bisa secara efektif meningkatkan proses dan hasil belajar siswa di kelas.

\section{Saran}

Adapun saran penelitian ini adalah sebagai berikut:

a. Guru dalam kinerjanya dituntut untuk selalu memperbaharui dan meningkatkan kompetensinya baik pada dimensi pedagogik, kepribadian, sosial dan professional. 
b. Peserta yang merupakan guru, hendaknya dapat memberikan balikan yang positif terhadap penggunaan metode tutor sebaya di dalam kelas sehingga proses pembelajaran dapat berlangsung lebih efektif dan efisien.

c. Penerapan metode tutor sebaya sebaiknya ditingkatkan terus menerus mengikuti perkembangan ilmu pengetahuan teknologi agar proses pembelajaran menjadi aktif, kreatif, dan menyenangkan.

\section{DAFTAR RUJUKAN}

Aqib, Zainal. 2013. Pengembangan Keprofesian Berkelanjutan Bagi Guru. Bandung: CV.Yrama Widya.

Ahmadi. 2006. Pengajaran Tutor Sebaya. Jakarta : Ghalia Indonesia Bungin, Burhan. 2007. Penelitian Kualitatif. Jakarta: Kencana Prenada Media Group

Halimatussakdiah. 2015. Laporan Hasil Penelitian: Pemenuhan Penilaian Kinerja Guru (Pkg) Bagi Guru Sdn. 101801 Dan Sdn. 108075 Kecamatan Deli Tua Kabupaten Deli Serdang. Lemlit, Unimed.

Kemendiknas. 2010. Pedoman

Pelaksanaan Penilaian Kinerja Guru (PK Guru). Kemendiknas Derektorat Jenderal Peningkatan Mutu Pendidikan dan Tenaga Kependidikan, Jakarta.

Kemendiknas. 2010. Peraturan Menteri Pendidikan Nasional
Nomor 35 Tahun 2010 Tentang Petunjuk Teknis Jabatan Fungsional Guru dan Angka Kreditnya, Jakarta.

Kemendiknas. 2011. Peraturan Menteri Negara Pendayagunaan Aparatur Negara dan Reformasi Birokrasi Nomor 16 Tahun 2009 Tentang Jabatan Fungsional Guru dan Angka Kreditnya. Pusat Pengembangan Profesi Pendidik Badan Pengembangan Sumber Daya Manusia Pendidikan dan Penjaminan Mutu Pendidikan Kemendiknas, Jakarta.

Suparno, 2007. Metode Tutor Sebaya dalam Pembelajaran. Jakarta : Rineka Cipta 